\title{
Identification of the MMP-1 regulation mechanism of benzopyrene, polycyclic aromatic hydrocarbons in foods
}

\author{
Chang Hee $\operatorname{Han}^{1}$, Nam Joo Kang ${ }^{1,2 *}$ \\ ${ }^{1}$ School of Food Science and Biotechnology, Kyungpook National University, Daegu 41566, Korea \\ ${ }^{2}$ Department of Integrative Biology, Kyungpook National University, Daegu 41566, Korea
}

\section{식품 중 다환방향족탄화수소(벤조피렌)의 MMP-1 조절 기전 규명

\author{
한창희 $^{1} \cdot$ 강남주 $^{1,2 *}$ \\ 1경북대학교 식품공학부 식품소재공학전공, ${ }^{2}$ 경북대학교 농생명융합공학과
}

\begin{abstract}
Benzo[a]pyrene-7,8-diol-9,10-epoxide (B[a]PDE) has been reported to cause various pathological lesions in humans via activation of the aryl hydrocarbon receptor (AhR) pathway. However, the molecular mechanism by which $B[a] P D E$ regulates signaling pathways during skin aging remains unclear. The present study investigated the effects of B[a]PDE on the expression of matrix metalloproteinase-1 (MMP-1), which is a major enzyme responsible for collagen damage, and its regulation of skin aging-related signaling pathways in $\mathrm{HaCaT}$ human keratinocyte cells. MMP-1 expression was increased by B[a]PDE treatment, and mitogen-activated protein kinase (MAPK) inhibitors suppressed B[a]PDE-induced MMP-1 expression. Furthermore, a-naphthoflavone (a-NF, AhR antagonist), PP2 (c-Src inhibitor), and gefitinib (EGFR inhibitor) attenuated the B[a]PDE-induced phosphorylation of and p38 and their upstream kinases such as c-Raf, MEK, and MKK3/6. These results suggest that AhR, c-Src, and epidermal growth factor receptor (EGFR) activations are necessary for B[a]PDE-induced MMP-1 upregulation by modulation of MAPK pathway activation. B[a]PDE also stimulates the phosphorylation of ERK via c-Src-dependent EGFR transactivation. These results demonstrate a novel mechanism by which B[a]PDE induces MMP-1 expression through the activation of AhR, c-Src, and EGFR in non-genetic pathways. Thus, it is indicated that the molecular mechanisms of MMP-1 expression by B[a]PDE-activated AhR play an important role in promoting skin aging.
\end{abstract}

Key words : benzo[a]pyrene-7,8-diol-9,10-epoxide, c-Src kinase, matrix metalloproteinase-1, human keratinocytes

\section{Introduction}

Polycyclic aromatic hydrocarbons (PAHs) are abundant in cooked foods, cigarette smoke and other environmental pollutions. In particular, PAHs are present in food products in large quantities due to thermal processes such as smoking, grilling and smoke drying. In addition, foods can become naturally contaminated by the accumulation of PAH in the food chain due to their lipophilic properties and tendency to accumulate in adipose tissue. PAH is classified as a carcinogen, so PAH exposure is a major concern for human health (Veyrand et al., 2013). Benzo[a]pyrene (B[a]P) is a representative compound of $\mathrm{PAH}$ and it can also converted to ultimate carcinogen, benzo[a]pyrene-7,8-diol9,10-epoxide (B[a]PDE), via cytochrome P450-mediated metabolism after entering human cells (Phillips, 1983). $\mathrm{B}[\mathrm{a}] \mathrm{P}$ and its metabolite (B[a]PDE) have been shown to be complete carcinogens in many animal models, including

*Corresponding author. E-mail : njkang@knu.ac.kr, Phone : +82-53-950-5753, Fax : +82-53-950-6750

Received 7 July 2020; Revised 16 July 2020; Accepted 24 July 2020.

Copyright (c) The Korean Society of Food Preservation.

This is an Open Access article distributed under the terms of the Creative Commons Attribution Non-Commercial License (http://creativecommons.org/licenses/by-nc/4.0) which permits unrestricted non-commercial use, distribution, and reproduction in any medium, provided the original work is properly cited. 
those for smoking-associated cancers, such as skin and lung cancers (Conney, 1982). However, direct role of B[a]PDE in skin-aging and its underlying molecular mechanisms have not been fully understood.

Binding of PAHs, such as 2,3,7,8,-tetrachlorodibenzop-dioxin (TCDD) or $\mathrm{B}[\mathrm{a}] \mathrm{P}$, to cytosolic aryl hydrocarbon receptor (AhR) causes dissociation of $\mathrm{AhR}$ from the multiprotein complex and its translocation into the nucleus where it dimerizes with AhR nuclear translocator (ARNT) (Reyes et al., 1992; Rowlands and Gustafsson, 1997). The AhR/ARNT heterodimer induces gene expression by binding to specific xenobiotic response element (XRE, 5' -GCGTG$\left.3^{\prime}\right)$ in promoter regions of a variety of target genes, such as the cytochrome P450 (CYP) enzymes CYP1A1 and CYP1B1, and increases their expression through transcriptional activation (Backlund and Ingelman-Sundberg, 2005; Nebert and Dalton, 2006; Petrulis and Perdew, 2002). These target genes encode proteins involved in growth, differentiation, and inflammation (Sutter et al., 1991; Yin et al., 1994). Beside the transcriptional induction of CYP1A1, AhR activation leads to a c-Src-dependent stimulation of epidermal growth factor receptor (EGFR) and its downstream targets MAPK signaling pathways (Kwon et al., 2003; Randi et al., 2008).

Ligand binding of the cytosolic AhR, leads to the dissociation of the multiprotein complex and the subsequent release of c-Src in the cytoplasm (Enan and Matsumura, 1996; Kohle et al., 1999). c-Src functions as a co-transducer of transmembrane signals emanating from a variety of polypeptide growth factor receptors, including EGFR (Luttrell et al., 1988). The c-Src kinase translocates to the cell membrane where it can interact with the EGFR in a bidirectional fashion; c-Src can bind and phosphorylate of EGFR, and vice versa (Belsches et al., 1997). The binding of downstream signaling proteins to phosphorylated EGFR tyrosines initiates several signaling cascades involved in cell proliferation, migration, differentiation, and tumor formation (Carpenter, 1999).

Matrix metalloproteinases (MMPs), as a hallmark in aging, are a family of over 20 different proteolytic enzymes that degrade the protein components of the extracellular matrix (ECM) (Mueller, 1996). MMP expression is essential for the skin remodeling and inappropriate expression and activity of MMPs is associated with various pathologies such as rheumatoid arthritis and tumor metastasis (Luca et al., 1997; Wandel et al., 2000). The expression of MMP-1 (collagenase), MMP-3 (stromelysin) and MMP-9 (gelatinase) is increased by various stimuli such as UV irradiation and inflammatory cytokines (Dasu et al., 2003; Fisher et al., 1996). Especially, in skin fibroblasts, active MMP-1 induces collagen fragmentation and functional changes similar to aged human skin (Xia et al., 2013). Tobacco smoke extracts impaired collagen biosynthesis significantly in cultured skin fibroblasts (Yin et al., 2000). In addition, B[a]P-induced AhR pathway activation increases the expression of MMP-1 mRNA and MMP-1 protein and promotes ECM degradation in $\mathrm{HaCaT}$ keratinocytes and human periodontal ligament cells (HPDLCs), vascular smooth muscle cells (VSMCs) (Meng et al., 2009; Tomokiyo et al., 2012). However, in human skin, the molecular mechanism of B[a]PDE-induced MMP-1 expression via AhR translocation has not been fully understood.

In this study, we investigated the molecular mechanisms of how AhR and c-Src are involved in MMP-1 expression by inducing $\mathrm{B}[\mathrm{a}] \mathrm{PDE}$ directly in $\mathrm{HaCaT}$ cells.

\section{Materials and methods}

\section{Chemicals}

$\mathrm{B}[\mathrm{a}] \mathrm{PDE}$, benzo[a]pyrene-7,8-diol-9,10-epoxide was purchased from MRIGlobal Chemical Carcinogen Repository (Kansas City, MO, USA). The AhR antagonist $\alpha$-naphthoflavone and mouse monoclonal anti- $\beta$-actin were obtained from Sigma-Aldrich Co. (St. Louis, MO, USA). Anti-human MMP-1 antibody was purchased from Neomarkers (Fremont, CA, USA). Primary antibodies recognizing phosphorylated c-Raf (Ser338), phosphorylated MEK1/2 (Ser217/221), phosphorylated JNK (Thr183/Tyr185), phosphorylated MKK4 (Ser257/Thr261), phosphorylated MKK3/6 (Ser189/207), phosphorylated EGFR (Tyr845), phosphorylated Src Family (Tyr 416), total c-Raf, total MEK1/2, total MKK4, total MKK3/6 and total EGFR were purchased from Cell Signaling Biotechnology (Danvers, MA, USA). The antibody against phosphorylated p38 (Thr180/Tyr182) was purchased from BD bioscience (San Jose, CA, USA). Primary antibodies recognizing phosphorylated ERK1/2 (Tyr 204), total ERK1/2, total p38, total c-Src and gefitinib (EGFR inhibitor) were obtained from Santa Cruz Bio- 
technology (Santa Cruz, CA, USA). Specific inhibitor of MEK (U0126), JNK (SP600125) and Src Family (PP2) were purchased from Tocris Bioscience (Bristol, UK). SB203580, a p38 inhibitor was obtained from Merck Millipore's Calbiochem $^{\circledR}$ (Billerica, MA, USA).

\section{Cell line and media}

The human immortalized keratinocyte cell line $\mathrm{HaCaT}$ was purchased from the American Type Culture Collection (Manassas, VA, USA). Dulbecco's Modified Eagle's Medium (DMEM), penicillin-streptomycin and 0.25\% trypsin-EDTA were purchased from GIBCO $^{\circledR}$ (Grand Island, NY, USA). Fetal bovine serum (FBS) was purchased from SigmaAldrich Co.

\section{Cell culture}

The HaCaT human keratinocytes were cultured in DMEM supplemented with $10 \% \mathrm{FBS}$ and $2 \mu \mathrm{M}$ penicillin/streptomycin at $37^{\circ} \mathrm{C}$ in humidified atmosphere with $5 \% \mathrm{CO}_{2}$.

\section{Western blot analysis}

Cells $\left(1 \times 10^{5}\right)$ were cultured in a $60 \mathrm{~mm}$ in diameter dish for $24 \mathrm{~h}$, then, they were starved in serum-free medium for a further $24 \mathrm{~h}$ to eliminate the influence of FBS on the kinase activation. Cells were treated with various concentrations of inhibitors for $1 \mathrm{~h}$, and then treated with $0.5 \mu \mathrm{M}$ B[a]PDE. The harvested cells were disrupted and the supernatant fractions were boiled for $5 \mathrm{~min}$. The protein concentration was determined using a Bio-Rad protein assay kit (Bio-Rad Laboratories, Hercules, CA, USA) as described in the manufacturer's manual. Total cell lysates were separated by $8-10 \%$ sodium dodecyl sulfate-polyacrylamide gel electrophoresis (SDS-PAGE) and electrophoretically transferred to a polyvinylidene fluoride (PVDF) microporous membrane (EMD Millipore Co., Billerica, MA, USA). After blotting, the membrane was incubated with the specific primary antibodies at $4^{\circ} \mathrm{C}$ overnight. After hybridization with secondary antibodies, the protein bands were visualized using an Amersham ECL prime western blotting detection system (GE Healthcare, Buckinghamshire, UK).

\section{Statistical analysis}

Data are expressed as means $\pm \mathrm{SD}$. Student's t-test was used for single statistical comparisions. A probability value of $\mathrm{p}<0.05$ was used as the criterion for statistical significance.

\section{Results and discussion}

\section{$\mathrm{B}$ [a]PDE stimulates MMP-1 expression in HaCaT cells}

Previous studies have shown that tobacco smoke extract accelerates skin aging through abnormal induction of MMPs. In the present study, we first investigated $\mathrm{B}[\mathrm{a}] \mathrm{PDE}-$ induced MMP-1 expression in $\mathrm{HaCaT}$ cells. The treatment with $\mathrm{B}[\mathrm{a}] \mathrm{PDE}$ at $1 \mu \mathrm{M}$ for $1-6 \mathrm{~h}$ significantly induced MMP-1 expression in a time-dependent manner (Fig. 1A and $1 \mathrm{~B})$. Next, treatment with $\mathrm{B}[\mathrm{a}] \mathrm{PDE}$ at $0.1-1 \mu \mathrm{M}$ for 6

(A)<smiles>OC1c2cc3ccc4cccc5ccc(c2-c3c54)C2OC1C2O</smiles>

Benzo[a]pyrene-7,8-diol-9,10-epoxide (B|a|PDE)

(B)

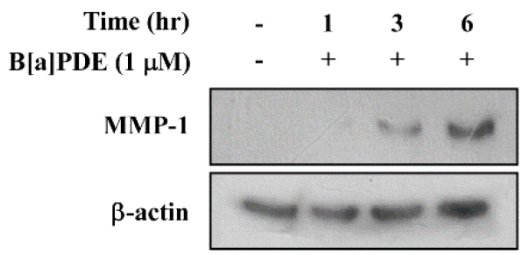

(C)

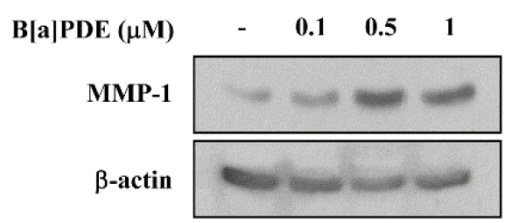

Fig. 1. Effect of B[a]PDE on MMP-1 expression in HaCaT cells.

(A) Chemical structures of benzo[a]pyrene-7,8-diol-9,10-epoxide (B[a]PDE). HaCaT cells were treated with $1 \mathrm{mM} \mathrm{B}[\mathrm{a}] \mathrm{PDE}$ for the indicated time $(1,3,6 \mathrm{~h})(\mathrm{B})$ or $\mathrm{B}[\mathrm{a}] \mathrm{PDE}$ at the indicated concentrations $(0.1,0.5,1 \mu \mathrm{M})$ for $6 \mathrm{~h}(\mathrm{C})$. The protein levels of MMP-1 and $\beta$-actin were determined using Western blot analysis as described in Materials and methods. Presented data are representative of three independent experiments that gave similar results. 
h significantly induced MMP-1 expression at $0.5 \mu \mathrm{M}$ (Fig. 1C). Taken together, these data clearly show that MMP-1 expression was increased by $\mathrm{B}[\mathrm{a}] \mathrm{PDE}$ at $0.5 \mu \mathrm{M}$ for $6 \mathrm{~h}$.

\section{$\mathrm{B}$ [a]PDE-induced MMP-1 up-regulation by mo- dulating the activation of MAPK pathways}

The MAPK signaling pathway is necessary for the regulation of MMP expression. Additionally, the previous study demonstrated a novel signaling pathway by which AhR agonists elevated intracellular calcium levels leading to increased MMP-1 expression through MAPK pathways in bronchial epithelial cell lines (Lee et al., 2015). To determine whether the activation of MAPK pathways increases MMP-1 expression in $\mathrm{HaCaT}$ cells exposed to B[a]PDE, the cells were pretreated with MAPK inhibitors at $5-20 \mu \mathrm{M}$ for $1 \mathrm{~h}$ before being exposed to $\mathrm{B}[\mathrm{a}] \mathrm{PDE}$ at $0.5 \mu \mathrm{M}$. U0126 (MEK inhibitor) completely blocked B[a]PDE-induced MMP-1 expression (Fig. 2A). In addition, SB203580 (p38 inhibitor) and SP600125 (JNK inhibitor) significantly suppressed B[a]PDE-induced MMP-1 expression in a dosedependent manner (Fig. 2B and $\mathrm{C}$ ). These results indicated that up-regulation of $\mathrm{B}[\mathrm{a}] \mathrm{PDE}$-induced MMP-1 occurs through the MAPK pathways in $\mathrm{HaCaT}$ cells.

\section{AhR activation is necessary for $B$ [a]PDE-induced} MMP-1 expression and phosphorylation of ERK, p38, JNK and their upstream kinases

Previous reports demonstrated the stimulation of MMP-1 expression through the activation of the AhR pathway in melanoma cells, vascular smooth muscle cells, and urothelial carcinoma cells (Ishida et al., 2010; Meng et al., 2009; Vogeley et al., 2019). To find out whether B[a]PDE is dependent on AhR to activate the MAPK pathways, we determined MMP-1 expression in HaCaT cells treated with $\mathrm{B}[\mathrm{a}] \mathrm{PDE}$ in the presence of $\alpha$-Naphthoflavone $(\alpha-\mathrm{NF})$, a classical AhR antagonist. These results suggested that $\alpha-\mathrm{NF}$ inhibits the B[a]PDE-induced MMP-1 expression (Fig. 3A) and phosphorylation of c-Raf/MEK/ERK, MKK3/6/p38, and MKK4/7/JNK signaling pathways in a dose-dependent manner (Fig. 3B, C and D). Consequently, AhR has been shown to play a major role in B[a]PDE-induced MMP-1 expression and c-Raf/MEK/ERK, MKK3/6/p38, and MKK4/ 7/JNK phosphorylation.
(A)

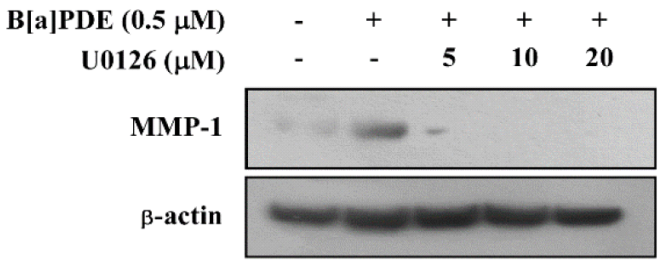

(B)

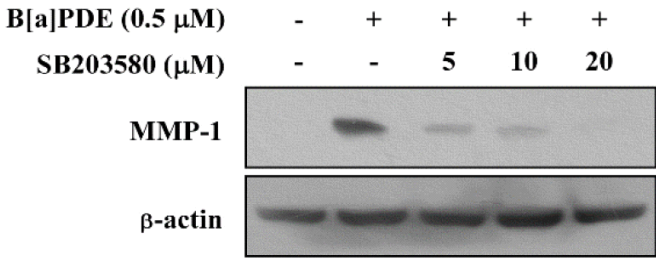

(C)

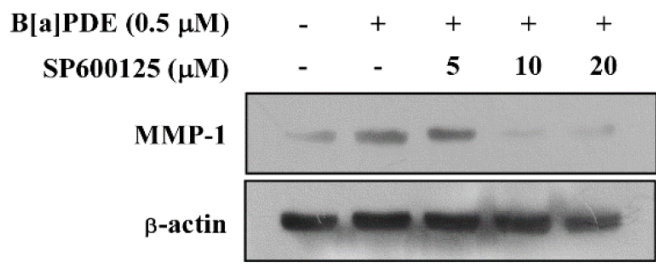

Fig. 2. Effect of U0126, SB203580 or SP600125 on B[a]PDEinduced MMP-1 expression in $\mathrm{HaCaT}$ cells.

$\mathrm{HaCaT}$ cells were treated with U0126 (A), SB203580 (B) or SP600125 (C) at the indicated concentrations $(5,10,20 \mu \mathrm{M})$ for $1 \mathrm{~h}$ before being exposed to $0.5 \mathrm{mM} \mathrm{B}[\mathrm{a}] \mathrm{PDE}$ and harvested $6 \mathrm{~h}$ later. The cells were disrupted, and the level of the MMP-1 protein was determined using Western blot analysis. Presented data are representative of three independent experiments that gave similar results.

C-Src modulates B[a]PDE-induced MMP-1 expression via phosphorylation of ERK, p38, JNK, and their upstream kinases

c-Src kinase is at least one of the earliest and the most upstream components of toxic signaling of the $\mathrm{AhR}$ activated by 2,3,7,8-tetrachlorodibenzo-p-dioxin (TCDD) through the post-transcriptional process. TCDD were mediated through a c-Src-dependent activation of the extracellular signal-regulated kinases $1 / 2$ (ERK1/2) in MCF10A cells (Mazina et al., 2004). To confirm whether c-Src involved in B[a]PDE-induced MMP-1 expression and phosphorylation of MAPK, HaCaT cells were cultured in the presence of the PP2 (c-Src inhibitor) at 2.5 and $5 \mu \mathrm{M}$. 
(A)

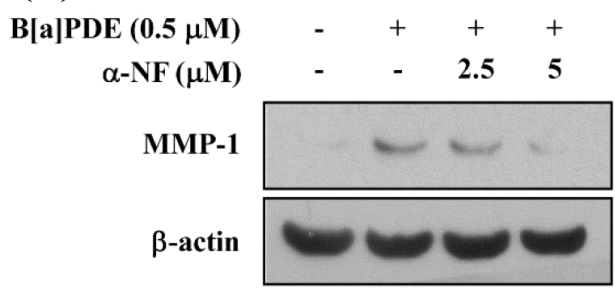

(C)

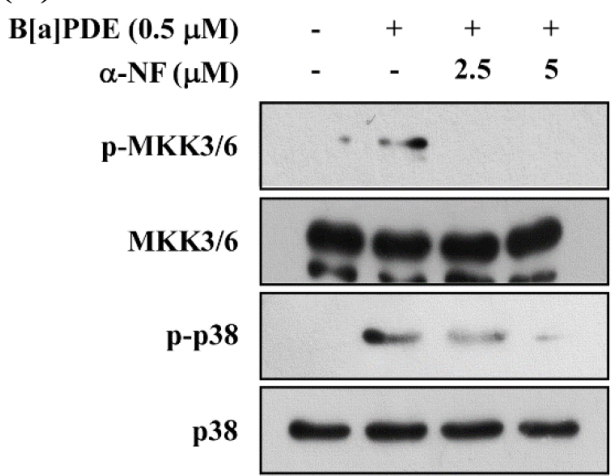

(B)

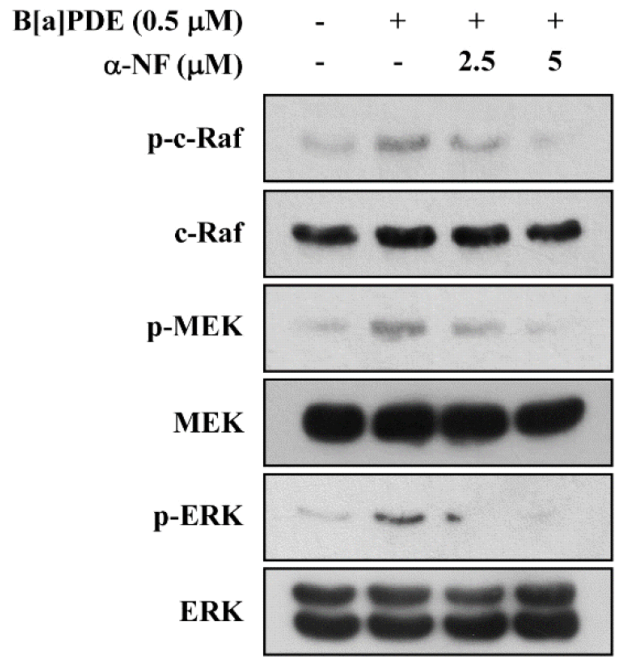

(D)

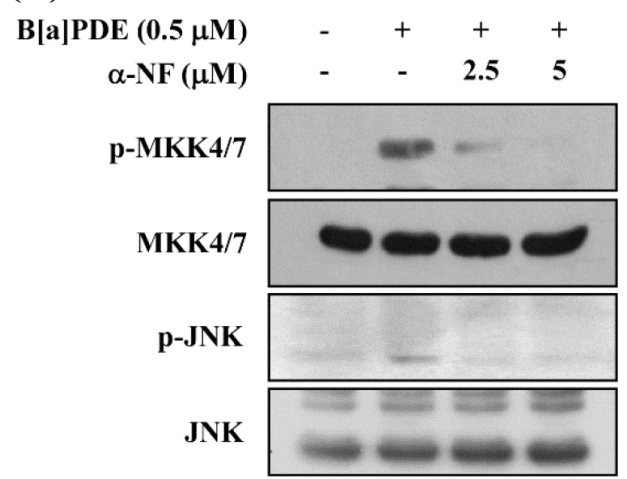

Fig. 3. Effect of $\alpha$-naphthoflavone on B[a]PDE-induced phosphorylation of ERK, p38 and their upstream kinases.

After pretreatment of $\alpha$-naphthoflavone for $1 \mathrm{~h}$, HaCaT cells were exposed to B[a]PDE for an additional $6 \mathrm{~h}$ (MMP-1) or for $1 \mathrm{~h}$ (p-ERK and $\mathrm{p}$-p38) or for $30 \mathrm{~min}$ (p-MEK and p-MKK3/6) or for $15 \mathrm{~min}$ (p-c-Raf). The protein levels of MMP-1 (A), phosphorylated- or total-c-Raf, MEK and ERK (B) and phosphorylated- or total-MKK3/6 and p38 (C) were determined by Western blot analysis. Presented data are representative of three independent experiments that gave similar results.

Pretreatment of the cells with PP2 reduced B[a]PDE-induced MMP-1 expression (Fig. 4A). Furthermore, PP2 significantly reduced $\mathrm{B}[\mathrm{a}] \mathrm{PDE}$-induced phosphorylation of c-Raf, MEK and ERK (Fig. 4B), MKK3/6/p38 and MKK4/7/JNK (Fig. $4 \mathrm{C}$ and $\mathrm{D})$.

\section{EGFR is involved in $\mathrm{B}[\mathrm{a}] \mathrm{PDE}$-induced MMP-1 up- regulation by modulating the activation of ERK, p38, JNK, and their upstream kinases}

Activation of the AhR leads to rapid activation of soluble tyrosine kinase c-Src. Activated c-Src is capable of phosphorylating cell-surface receptors such as EGFR, which induce subsequent stimulation of downstream MAPK signaling to regulate gene transcription (Xie et al., 2012). Several other studies have reported that exposure to TCDD and related xenobiotics like $\mathrm{B}[\mathrm{a}] \mathrm{P}$ or hexachlorobenzene results in activation of the mitogen-activated signaling pathways, which is mostly a downstream targets of EGFR (Kwon et al., 2003; Randi et al., 2008). In this study, we examined the effect of gefitinib (EGFR inhibitor) on B[a]PDE-induced MMP-1 expression and phosphorylation of MAPKs. Pretreatment with Gefitinib inhibits the B[a]PDEinduced MMP-1 expression (Fig. 5A) and phosphorylation of c-Raf/MEK/ERK, MKK3/6/p38, and MKK4/7/JNK and their upstream kinases (Fig. 5B, C and D). These results suggest that $\mathrm{c}$-Src and EGFR are required for the 
(A)

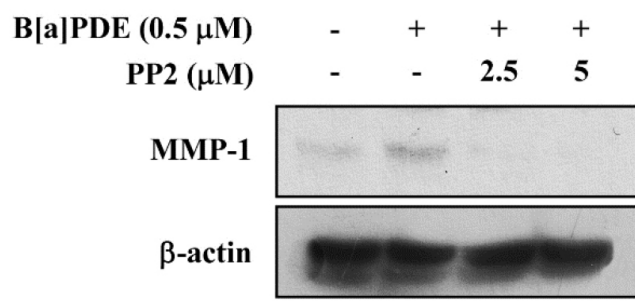

(C)

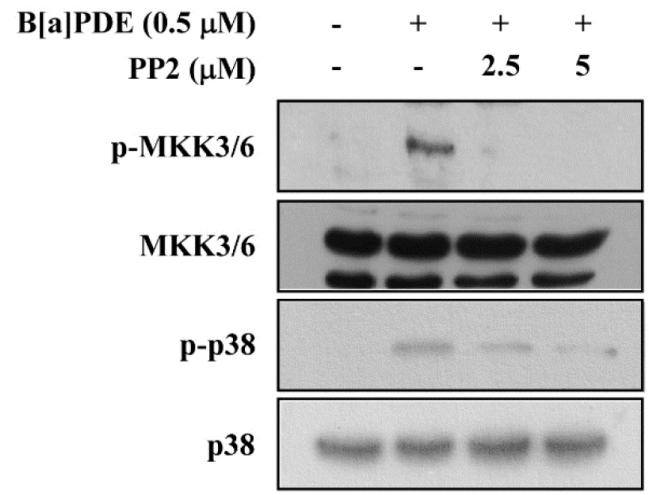

(B)

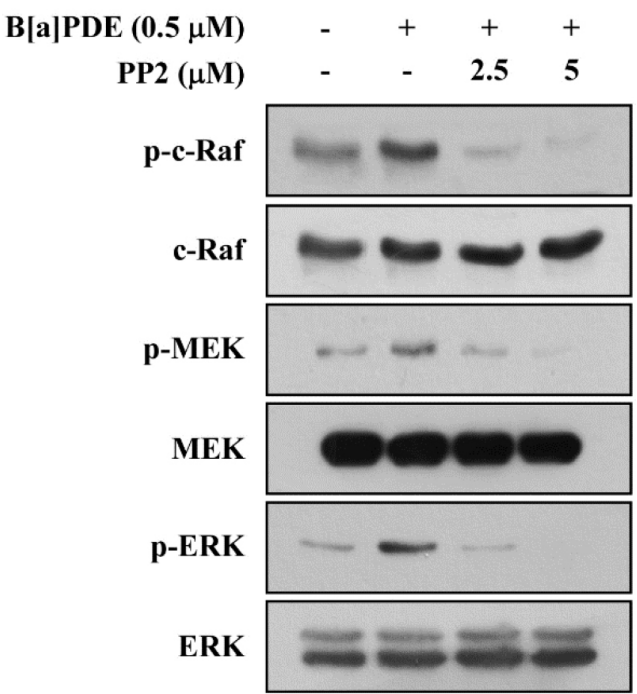

(D)

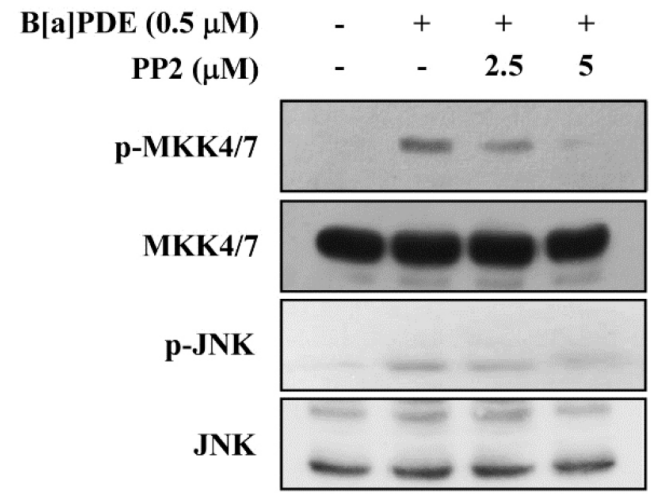

Fig. 4. Effect of PP2 on B[a]PDE-induced phosphorylation of ERK, p38 and their upstream kinases.

After pretreatment of PP2 for $1 \mathrm{~h}$, HaCaT cells were exposed to B[a]PDE for an additional $6 \mathrm{~h}$ (MMP-1) or for $1 \mathrm{~h}$ (p-ERK and p-p38) or for $30 \mathrm{~min}$ (p-MEK and p-MKK3/6) or for 15 min (p-c-Raf). The protein levels of MMP-1 (A), phosphorylated- or total-c-Raf, MEK and ERK (B) and phosphorylated- or total-MKK3/6 and p38 (C) were determined by Western blot analysis. Presented data are representative of three independent experiments that gave similar results.

B[a]PDE-induced MMP-1 up-regulation and activation of MAPK pathways in HaCaT cells.

\section{$B$ [a]PDE stimulates phosphorylation of ERK and c-Src in HaCaT cells}

EGFR can be transactivated by other agents, such as activation of Src family, and is known as mediators of c-Src-dependent ERK activation (Zhang et al., 2007). To identify c-Src association to the EGFR in HaCaT cells, we investigated the action of $\mathrm{B}[\mathrm{a}] \mathrm{PDE}$ on the phosphorylation status of ERK and c-Src. As shown in Fig. 6A, B[a]PDEinduced ERK phosphorylation was detected at 5-30 min and returned to close baseline until $60 \mathrm{~min}$. In addition, B[a]PDE-induced c-Src phosphorylation was detected at 15 min and persisted for $\geq 60$ min (Fig. 6B). As anticipated, these results confirmed that $\mathrm{B}[\mathrm{a}] \mathrm{PDE}$ stimulates phosphorylation of ERK via c-Src-dependent EGFR transactivation.

Based on the current findings, in Fig. 7, we can propose a model that represents signaling pathways for $\mathrm{B}[\mathrm{a}]$ PDE-induced MMP-1 expression in human keratinocytes. In unstimulated cells, c-Src and $\mathrm{AhR}$ coexist in a protein complex that also likely contains heat-shock protein 90 (HSP90) (Bock and Kohle, 2006). Binding of B[a]PDE to 
(A)

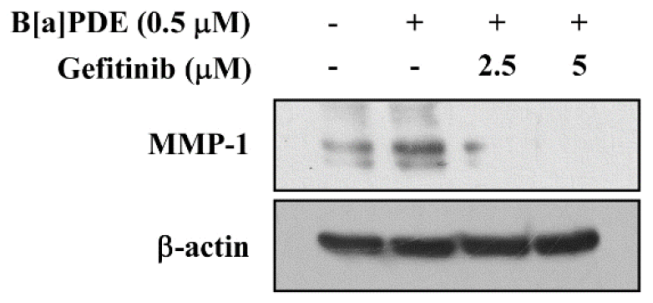

(B)

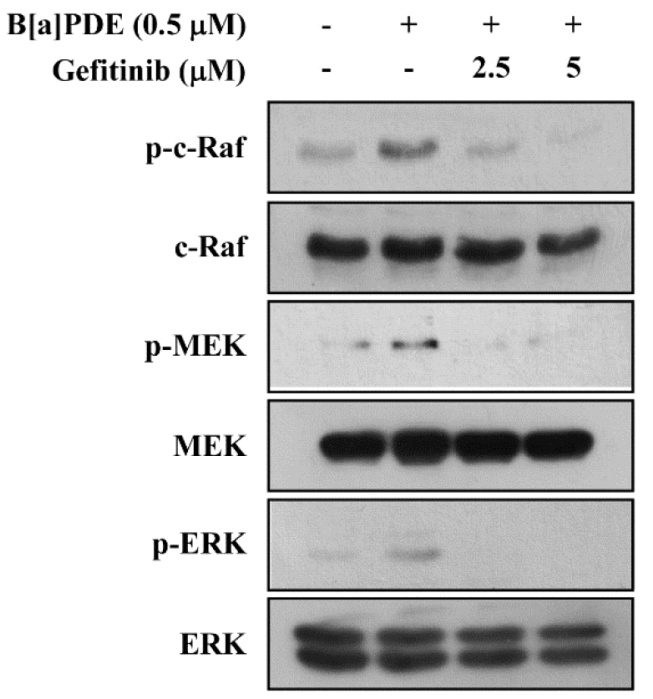

(D)

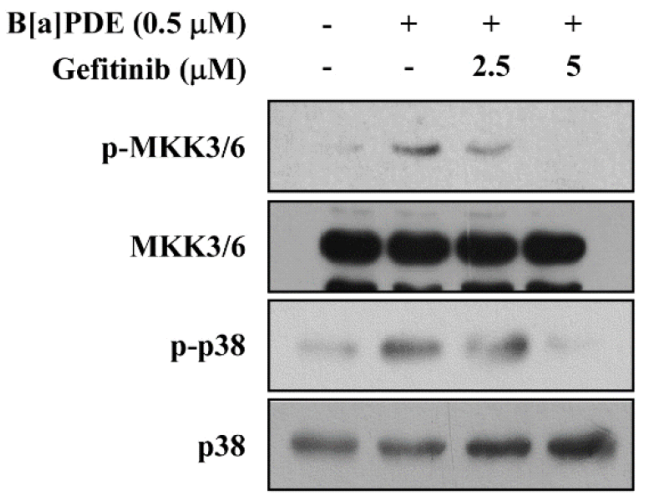

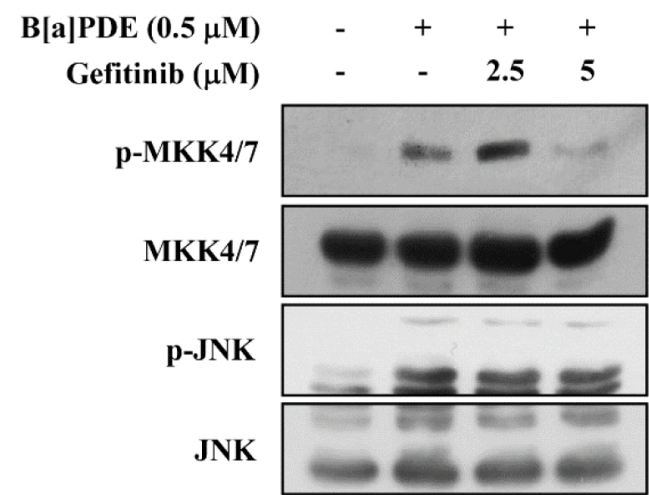

Fig. 5. Effect of gefitinib on B[a]PDE-induced phosphorylation of ERK, p38 and their upstream kinases.

After pretreatment of gefitinib for $1 \mathrm{~h}, \mathrm{HaCaT}$ cells were exposed to B[a]PDE for an additional $6 \mathrm{~h}$ (MMP-1) or for $1 \mathrm{~h}$ (p-ERK and p-p38) or for $30 \mathrm{~min}$ (p-MEK and $\mathrm{p}-\mathrm{MKK} 3 / 6$ ) or for $15 \mathrm{~min}$ (p-c-Raf). The protein levels of MMP-1 (A), phosphorylated- or total-c-Raf, MEK and ERK (B) and phosphorylated- or total-MKK3/6 and p38 (C) were determined by Western blot analysis. Presented data are representative of three independent experiments that gave similar results.

(A)

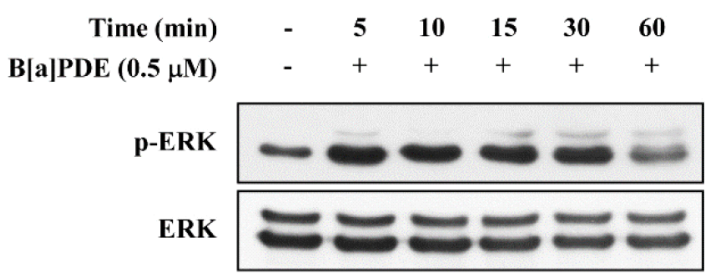

(B)

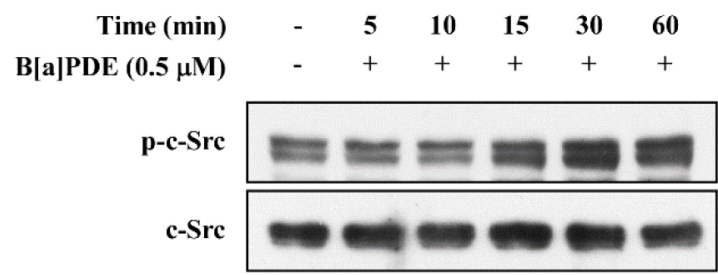

Fig. 6. Effects of B[a]PDE on phosphorylation of ERK and c-Src in HaCaT cells.

(A) Time-course for B[a]PDE-induced ERK phosphorylation in HaCaT cells. (B) Time-course for B[a]PDE-induced c-Src phosphorylation in HaCaT cells. Cells were treated with $0.5 \mu \mathrm{M} \mathrm{B}$ [a]PDE for the indicated time at $37^{\circ} \mathrm{C}$. Phosphorylated and total expression levels of ERK and c-Src were determined using Western blot analysis. Presented data are representative of three independent experiments that gave similar results. 


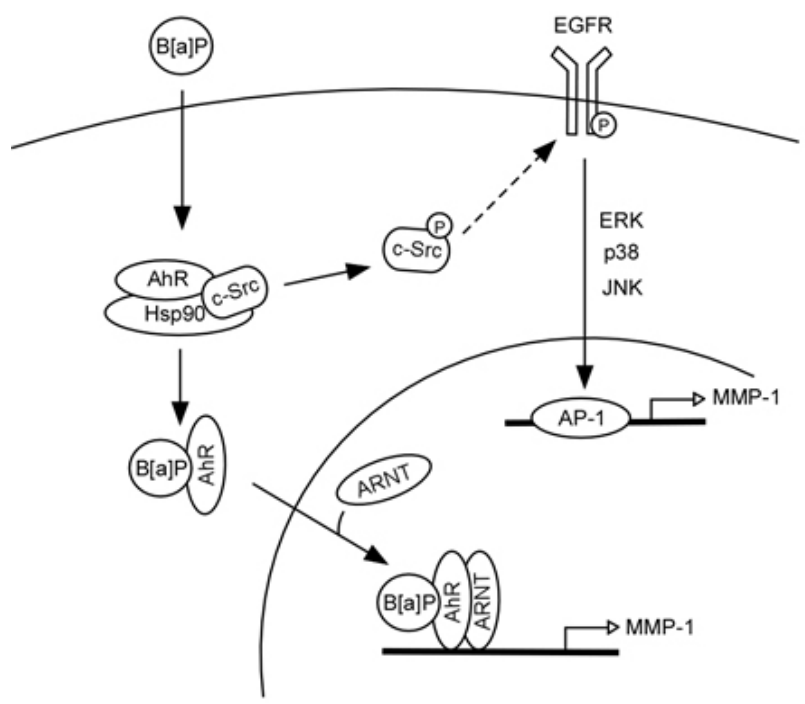

Fig. 7. A model showing that c-Src mediated EGFR activation is involved in the expression of MMP-1 induced by B[a] PDE in human keratinocytes.

Binding of AhR by a ligand, e.g., B[a]PDE, results in phosphorylation of c-Src kinase at Tyr416. Phosphorylated c-Src (Tyr416) activates EGFR, which promotes transcription of MMP-1 by activating downstream MAPK signaling. The binding of B[a]PDE to AhR also causes the translocation of AhR from the cytoplasm to the nucleus to act as transcription factor for the MMP-1 gene.

AhR activates c-Src (Tyr416 phosphorylation), which in turn activates EGFR (Tyr845 phosphorylation). Activated EGFR promotes MAPK signaling and MMP-1 transcription and consequently stimulates ECM degradation. Activated AhR can also be translocated to the nucleus and acts as a transcription factor, directly regulating MMP-1 gene expression.

In conclusion, the results of this study show a novel mechanism by which B[a]PDE induces MMP-1 expression through activation of AhR, c-Src and EGFR in non-genetic pathways. Taken together, it can be suggested that the mechanism of $\mathrm{B}[\mathrm{a}] \mathrm{PDE}-$ induced MMP-1 expression via multiple signaling plays an important role in promoting cellular processes such as skin aging.

\section{Summary}

Benzo[a]pyrene-7,8-diol-9,10-epoxide(B[a]PDE)는 흔한 발 암원으로 잘 알려져 있는 benzo[a]pyrene(B[a]P)의 대사물질 로, 식품에서 다수 발견되고 있다. 체내에 흡수되어 다양한 병변을 유발한다고 알려져 있지만, B[a]PDE의 피부노화 유 도 과정은 지금까지 명확하게 규명되지 않았다. 본 연구는
$\mathrm{B}[\mathrm{a}] \mathrm{PDE}$ 가 콜라겐 분해효소인 MMP- 1 의 발현에 미치는 영 향과 그 자세한 분자적 기전을 밝히고, $\mathrm{B}[\mathrm{a}] \mathrm{PDE}$ 로 유도된 MMP-1 발현에서 c-Src의 직접적인 역할을 인간각질세포 (HaCaT human keratinocyte cells) 모델을 이용하여 규명하 였다. $\mathrm{B}[\mathrm{a}] \mathrm{PDE}$ 는 $0.5 \mu \mathrm{M}$ 농도로 6시간 처리 시, MMP-1의 발현을 증가시켰으며, $\mathrm{B}[\mathrm{a}] \mathrm{PDE}$ 로 유도된 MMP- 1 의 발현은 mitogen-activated protein kinase(MAPK) 억제제에 의해 감 소되었다. AhR 길항제인 $\alpha$-naphthoflavone( $\alpha$-NF)과 c-Src 억 제제인 PP2, epidermal growth factor receptor(EGFR) 억제 제인 gefitinib을 각각 처리시 모두 $\mathrm{B}[\mathrm{a}] \mathrm{PDE}$ 로 유도된 MMP-1의 발현을 감소시켰을 뿐만 아니라, ERK와 p38의 인 산화 및 상위 인산화 효소에 해당하는 c-Raf, MEK와 $\mathrm{MKK} 3 / 6$ 의 인산화를 감소시켰다. 또한, $\mathrm{ERK}$ 와 c-Src의 인산 화는 공통적으로 $\mathrm{B}[\mathrm{a}] \mathrm{PDE}$ 처리 후 15 분과 30 분에서 증가하 는 경향을 보였다. 따라서, $\mathrm{B}[\mathrm{a}] \mathrm{PDE}$ 로 유도된 MAPK 신호전 달에 의한 MMP-1 상향조절 과정에서 $\mathrm{AhR}$ 과 c-Src, EGFR 의 활성화가 필수적일 것으로 사료된다. 특히, 본 논문은 $\mathrm{c}-\mathrm{Src}$ 가 B[a]PDE로 유도된 피부노화 과정에 관여한다는 첫 번째 연구결과라는 점에서 그 의의가 있다.

\section{Conflict of interests}

The authors declare no potential conflict of interest.

\section{ORCID}

Chang Hee Han https://orcid.org/0000-0001-6992-4306

Nam Joo Kang https://orcid.org/0000-0003-1500-2845

\section{References}

Backlund M, Ingelman-Sundberg M. Regulation of aryl hydrocarbon receptor signal transduction by protein tyrosine kinases. Cell Signalling, 17, 39-48 (2005)

Belsches AP, Haskell MD, Parsons SJ. Role of c-Src tyrosine kinase in EGF-induced mitogenesis. Front Biosci, 2, d501-518 (1997)

Bock KW, Kohle C. Ah receptor: Dioxin-mediated toxic responses as hints to deregulated physiologic functions. Biochem Pharmacol, 72, 393-404 (2006)

Carpenter G. Employment of the epidermal growth factor receptor in growth factor-independent signaling pathways. J Cell Biol, 146, 697-702 (1999)

Conney $\mathrm{AH}$. Induction of microsomal enzymes by foreign 
chemicals and carcinogenesis by polycyclic aromatic hydrocarbons: G. H. A. clowes memorial lecture. Cancer Res, 42, 4875-4917 (1982)

Dasu MR, Barrow RE, Spies M, Herndon DN. Matrix metalloproteinase expression in cytokine stimulated human dermal fibroblasts. Burns, 29, 527-531 (2003)

Enan E, Matsumura F. Identification of c-Src as the integral component of the cytosolic Ah receptor complex, transducing the signal of 2,3,7,8-tetrachlorodibenzo-p-dioxin (TCDD) through the protein phosphorylation pathway. Biochem Pharmacol, 52, 1599-1612 (1996)

Fisher GJ, Datta SC, Talwar HS, Wang ZQ, Varani J, Kang S, Voorhees JJ. Molecular basis of sun-induced premature skin ageing and retinoid antagonism. Nature, 379, 335-339 (1996)

Ishida M, Mikami S, Kikuchi E, Kosaka T, Miyajima A, Nakagawa K, Mukai M, Okada Y, Oya M. Activation of the aryl hydrocarbon receptor pathway enhances cancer cell invasion by upregulating the MMP expression and is associated with poor prognosis in upper urinary tract urothelial cancer. Carcinogenesis, 31, 287-295 (2010)

Kohle C, Gschaidmeier H, Lauth D, Topell S, Zitzer H, Bock KW. 2,3,7,8-Tetrachlorodibenzo-p-dioxin (TCDD)mediated membrane translocation of c-Src protein kinase in liver WB-F344 cells. Arch Toxicol, 73, 152-158 (1999)

Kwon MJ, Jeong KS, Choi EJ, Lee BH. 2,3,7,8- Tetrachlorodibenzo-p-dioxin (TCDD)-induced activation of mitogen-activated protein kinase signaling pathway in Jurkat T cells. Pharmacol Toxicol, 93, 186- 190 (2003)

Lee YC, Hsiao NW, Tseng TS, Chen WC, Lin HH, Leu SJ, Yang EW, Tsai KC. Phage display-mediated discovery of novel tyrosinase-targeting tetrapeptide inhibitors reveals the significance of N-terminal preference of cysteine residues and their functional sulfur atom. Mol Pharmacol, 87, 218-230 (2015)

Luca M, Huang S, Gershenwald JE, Singh RK, Reich R, Bar-Eli M. Expression of interleukin-8 by human melanoma cells up-regulates MMP-2 activity and increases tumor growth and metastasis. Am J Pathol, 151, $1105-$ 1113 (1997)

Luttrell DK, Luttrell LM, Parsons SJ. Augmented mitogenic responsiveness to epidermal growth factor in murine fibroblasts that overexpress pp60c-src. Mol Cell Biol, 8,
497-501 (1988)

Mazina O, Park S, Sano H, Wong P, Matsumura F. Studies on the mechanism of rapid activation of protein tyrosine phosphorylation activities, particularly c-Src kinase, by TCDD in MCF10A. J Biochem Mol Toxicol, 18, 313321 (2005)

Meng D, Lv DD, Zhuang X, Sun H, Fan L, Shi XL, Fang J. Benzo[a]pyrene induces expression of matrix metalloproteinases and cell migration and invasion of vascular smooth muscle cells. Toxicol Lett, 184, 44-49 (2009)

Mueller BM. Different roles for plasminogen activators and metalloproteinases in melanoma metastasis. Current Topics in Microbiology and Immunology, 213, 65-80 (1996)

Nebert DW, Dalton TP. The role of cytochrome P450 enzymes in endogenous signalling pathways and environmental carcinogenesis. Nat Rev Cancer, 6, 947-960 (2006)

Petrulis JR, Perdew GH. The role of chaperone proteins in the aryl hydrocarbon receptor core complex. Chem Biol Interact, 141, 25-40 (2002)

Phillips DH. Fifty years of benzo(a)pyrene. Nature, 303, 468-472 (1983)

Randi AS, Sanchez MS, Alvarez L, Cardozo J, Pontillo C, Kleiman de Pisarev DL. Hexachlorobenzene triggers AhR translocation to the nucleus, c-Src activation and EGFR transactivation in rat liver. Toxicol Lett, 177, 116-122 (2008)

Reyes H, Reisz-Porszasz S, Hankinson O. Identification of the Ah receptor nuclear translocator protein (Arnt) as a component of the DNA binding form of the Ah receptor. Science, 256, 1193-1195 (1992)

Rowlands JC, Gustafsson JA. Aryl hydrocarbon receptormediated signal transduction. Crit Rev Toxicol, 27, 109-134 (1997)

Sutter TR, Guzman K, Dold KM, Greenlee WF. Targets for dioxin: Genes for plasminogen activator inhibitor-2 and interleukin-1 beta. Science, 254, 415-418 (1991)

Tomokiyo A, Maeda H, Fujii S, Monnouchi S, Wada N, Hori K, Koori K, Yamamoto N, Teramatsu Y, Akamine A. Alternation of extracellular matrix remodeling and apoptosis by activation of the aryl hydrocarbon receptor pathway in human periodontal ligament cells. J Cell Biochem, 113, 3093-3103 (2012) 
Veyrand B, Sirot V, Durand S, Pollono C, Marchand P, Dervilly-Pinel G, Tard A, Leblanc JC, Le Bizec B. Human dietary exposure to polycyclic aromatic hydrocarbons: Results of the second French Total Diet Study. Environment International, 54, 11-17 (2013)

Vogeley C, Esser C, Tuting T, Krutmann J, HaarmannStemmann T. Role of the aryl hydrocarbon receptor in environmentally induced skin aging and skin carcinogenesis. Int J Mol Sci, 20, 6005 (2019)

Wandel E, Grasshoff A, Mittag M, Haustein UF, Saalbach A. Fibroblasts surrounding melanoma express elevated levels of matrix metalloproteinase-1 (MMP-1) and intercellular adhesion molecule-1 (ICAM-1) in vitro. Exp Dermatol, 9, 34-41 (2000)

Xia W, Hammerberg C, Li Y, He T, Quan T, Voorhees JJ, Fisher GJ. Expression of catalytically active matrix metalloproteinase-1 in dermal fibroblasts induces collagen fragmentation and functional alterations that resemble aged human skin. Aging Cell, 12, 661-671 (2013)
Xie G, Peng Z, Raufman JP. Src-mediated aryl hydrocarbon and epidermal growth factor receptor cross talk stimulates colon cancer cell proliferation. Am J Physiol Gastrointest Liver Physiol, 302, G1006-1015 (2012)

Yin H, Li Y, Sutter TR. Dioxin-enhanced expression of interleukin-1 $\beta$ in human epidermal keratinocytes: Potential role in the modulation of immune and inflammatory responses. Exp Clin Immunogenet, 11, 128-135 (1994)

Yin L, Morita A, Tsuji T. Alterations of extracellular matrix induced by tobacco smoke extract. Arch Dermatol Res, 292, 188-194 (2000)

Zhang J, Kalyankrishna S, Wislez M, Thilaganathan N, Saigal B, Wei W, Ma L, Wistuba II, Johnson FM, Kurie JM. Src-family kinases are activated in non-small cell lung cancer and promote the survival of epidermal growth factor receptor-dependent cell lines. Am J Pathol, 170, 366-376 (2007) 